\title{
Analysis of The Implementation of Character Education at Junior High School in Sumbawa Besar Regency
}

\author{
Nining Andriani* \\ Study Program of Economic Education \\ University of Samawa \\ Sumbawa Indonesia \\ niningunsa@gmail.com
}

\author{
Ilham Handika \\ Study Program of Biology Education \\ University of Samawa \\ Sumbawa, Indonesia \\ ilham31@gmail.com
}

\author{
I Made Sentaya \\ Study Program of Education \\ Technology \\ University of Samawa \\ Sumbawa, Indonesia \\ msentaya@gmail.com
}

\author{
R Rahmawati \\ Study Program of English Education \\ Academy of Teaching and Education Paracendekia NW \\ Sumbawa, Indonesia \\ rahmawatistkip@gmail.com
}

\author{
I Gusti Made Sulindra \\ Study Program of Education Technology \\ University of Samawa \\ Sumbawa, Indonesia \\ sulindra.igusti@gmail.com
}

\begin{abstract}
Education is the most important aspect in a person's life. Through education, a person can be seen as respectable, have a good career and can behave according to the norms. Besides that, education also has a very important role. With high education, a person can have a good job, live a good life and improve his social status. Higher education will able to change a person's behavior and character to be better. This study aims to determine the implementation of character education at Sumbawa Besar Regency. The approach used in this research was qualitative research, since it was focusing on the understanding of social phenomena from the perspective of the participants. Data collection techniques used in the study were observation, interviews, and documentation. The analysis techniques in this study are data reduction, presentation, and drawing conclusion or verification. In order to obtain the validity of the data so that will obtain the valid findings, it is necessary to examine its reliability by using technical triangulation and source triangulation. The results of this study are that planning for character education in Sumbawa has been arranged by the principal and then the teacher is instructed to make a syllabus and lesson plans to insert those values in the learning process. The implementation of character education in teacher learning activities inserts some character values in the learning process. Furthermore, the most common characters that implemented in learning processes are religious, honesty, discipline, responsibility, and hard work.
\end{abstract}

Keywords: Implementation, Character Education, Junior High School of Sumbawa

\section{INTRODUCTION}

Education is one of the most important aspects in a person's life because by having it, a person can be seen as respectable one, has a good career and can behave according to the norms. In addition, education also has a very important role, especially related to character education. Character education can be interpreted as a serious effort by developing, triggering, and empowering a positive personality through exemplary, studies (history and biographies of the great thinkers), and the emulation practices (the maximum effort to realize wisdom from what is observed and learned[1]. Character can be defined as a psychosocial element associated with education and environmental context. Based on the behavioral aspect, character emphasizes the personality elements that individuals have from birth [2]

Based on the results of research by Nining Andriani, Education in schools is not only learning material, but also education which is essentially the development of attitudes and souls in every student. If the school is able to teach positive attitudes and souls to each student, the students will be able to develop a good attitude and lessons from the school. The students will implement the characters they built in dealing with various situations that can occur internally and externally [3].

Character education is the character that involves aspects theory of cognitive, feeling, and action, without these three aspects, character education will not be effective [4]. Character education contains 3 main elements, namely knowing the good, loving the good, and doing the good [5].

The terms of character and personality or disposition are often used interchangeably. But, the word character means normative and ethical senses and stated that character is personality evaluated devaluated, which means that character is a valued personality, and personality is a priceless character [6]. According to the Islamic perspective, theoretical character education has actually existed since Islam was revealed in the world, along with the prophet Muhammad SAW to improve human morals. Basically, the term of character is often associated with the term morals or ethics. Character can be interpreted as the original state that exists in a person that differentiates himself from others. Morals are everything that has been attached firmly in a person, which produce the acts without prioritizing thought first. Ethic is a good and bad teachings regarding actions and attitudes that provide evaluation based on norms prevailing in society. Whereas moral refers to things that have been accepted by a community, morals more emphasize on human actions or behavior. Character education is also interpreted as 
moral education with the aim of developing the ability of students to be able to choose between good and bad things. Character education is the education that places and develops noble characters in students, so that they have these characteristics to be applied and practiced in family or community life [7]. The objectives of character education are to form the strong society and nation, raise the society with noble character, tolerant, able to work cooperatively. In addition, character education also creates a nation to have a patriotic spirit, long-life learning, oriented to science and technology, and be righteous to the Almighty God.

The location of this present study was on a Private Islamic Junior High School in Sumbawa Regency. This school was built with the expectation can be an alternative quality education with integrative curriculum, which combines general education and religious education into a curriculum so that it can optimize the cognitive (aqliyah), affective (ruhiyah) and psychomotor (jasadiyah) in order to create balance of the science of qauliyah (revelation) and the science of qauniyah (ilham) and between aqliyah, ruhiyah and jasadiyya of the students. It will develop the young generation of Muslims who are knowledgeable, have a broader insight, and beneficial for the ummah because considering the condition of the moral behavior of students at this time is very concerning.

This is certainly influenced by the condition of character education they learned from the school environment or the community environment. Because teaching morals in schools at this time has not been given independently, the point is that it is still integrated with other subjects such as religious education and Pancasila education. These are the things that inspire this school to conducted the integrated Islamic education, namely to build the character of students who have excellence in rational thinking but do not forget the values contained in Islamic argument.

\section{METHODS}

The type of approach in this research is a qualitative. Qualitative approach is the data that is presented in the form of verbal words, not in the form of numbers. The research design used is ethnographic research that describes the existing phenomena. Data collection was conducted through observation and interviews. The subjects of this study were the principal, teachers and students. This research was conducted to analyze the implementation of character education for junior high school students in the district of Sumbawa. The targets of this research are the principal, teachers and students.

Data are facts or information that are used as a source of finding conclusions and making decisions. Based on the source of collection, data can be divided into 2 types, namely primary data and secondary data.

Primary data are stories or notes from school principals, teachers, and students in the form of information about the implementation of character education. The sources of data in this study were obtained from several informants as follows: The principal as a leader has a policy in implementing character education, the teacher is one of the school equipment that has a role in implementing character education policies in the teaching and learning process,
Students as one of the users who feel the direct impact of the application of character education.

To improve some of these sources, there are other supporting data sources, namely secondary data, which is additional data obtained from schools related to researchers, namely syllabus files and lesson plans files and also documentation. Data collection techniques used were observation and interviews

Data analysis techniques in this study are data reduction, data presentation, and drawing conclusion or verification [8]

\section{Data Reduction}

Data reduction is necessary because the data obtained is sufficiently large so that it needs to be recorded carefully and in detail. Reducing data means summarizing, selecting and focusing on important things, looking for themes and patterns. In reducing the results of interviews and observations with informants, researchers selecting the important things related to the implementation of character education for junior high school students in Sumbawa district.

\section{Data Presentation}

In qualitative research, data presentation can be done in the form of brief descriptions, charts, relationships between categories, flowcharts, etc. Qualitative research in data presentation is usually in the form of narrative text. Researchers present the data in the form of descriptions regarding the implementation of character education for junior high school students in Sumbawa district.

\section{Drawing Conclusion or Verification}

The initial conclusions described are still provisional and will change if no strong evidence is found to support it in the next data collection stage. If the conclusions described in the early stages are supported by valid and consistent evidence when the researcher collects data, then the conclusions described are credible conclusions. Findings can be in the form of a description of an object that was previously unclear and incomplete so that after the analysis it becomes clear and can be in the form of a causal or interactive relationship, hypothesis or theory.

In qualitative research, the data validity test includes credibility, transferability, dependability and confirmability.[9] To obtain the validity of the data, it is necessary to examine the credibility by using technical triangulation and source triangulation. Source triangulation is used to test the credibility of the data by checking the data that has been obtained through several sources. Technique triangulation is used to test the credibility of the data by checking the data to the same source with different techniques [10].

\section{RESULTS AND DISCUSSION}

\section{A. Results}

Character education is very important for developing and building the character of students, so it is carried out in the form of implementation character education. The following is an explanation of the results of research on the 
implementation of character education for junior high school students in Sumbawa Besar Regency.

1) The Plan of Character Education for Junior High School Students

In the planning process, character education has been implemented. Based on the results of the interview with Fakhruddin as the head of the junior high school said that:

"So, the planning has been conducted that we associate with the mandate of the characters that are regulated by the agency and we adjust to a religious approach, such as discipline, honesty, responsibility, hard work, we associate it with Islamic sciences and also accompany the memorization of the Al-Qur'an. In implementing the character values, we teach all students to always be on time in carrying out prayers when they hear the azan. If the students are late in praying, they will get a consequence, namely they have to collect 1.000 garbage and be supervised by their friends. With the consequences will make the students change and realize their mistakes. In trying to build character, I immediately handled the Dzuhur Prayer, dzikir and evaluated the students after praying". "(W/KP/L/27/07/20/at:10.30 WITA)". The results of the interview with the teacher found these following findings.

"The planning has been arranged by the principal and usually the teacher only implements it such as making syllabus and lesson plans. All teachers must be instructed before starting to teach in class, such as teachers must teach character values to students, namely religious values so that before the learning process begins, they must pray first. "(W/A/L/27/07/20/at: 11:30 WITA)".

In addition to conducting interviews, researchers also conducted observations of junior high school students in Sumbawa.

"At 10:20 the teacher conducts the learning process online via WhatsApp Group or Google Classroom with students because the learning process is currently being conducted at home". O/27/07/20/at: 10:15 WITA).

Based on the results of the analysis of the researcher documentation related to planning that the teacher in making the syllabus and the lesson plan (RPP) relates to character values, for example, in Civics subject "Grateful to the Almighty God for the enthusiasm and commitment of the founders of the country in formulating and establishing the basis of the state Pancasila". This material the teacher focuses on religious values, discipline and responsibility.

Based on the results of interviews, observations and documentation, it can be concluded that character education planning in this school every teacher must make learning devices that are adapted to the standard of learning content to be developed according to school conditions. Then the teacher combines character values and inserts a religious approach during the learning process.

2) The Implementation of Character Education in Junior High School

Character education for junior high school students in Sumbawa Besa Regency has been implemented. Based on the results of the interview with Fakhruddin as the principal said that:

"The implementation stage of the character values that is strengthened first is the habituation of students, so that every month there are targets that are achieved, for example honesty value during the exams. All teachers must concentrate on reminding students to be honest, because the value of honesty is more important than their test scores. But the level of student success is different, some are taught once they can and some are difficult because they have obstacles. The character must involve parents, not just rely on school (W/KP/27/07/20/pkl:10.30WITA)". The results of interviews with teachers regarding the implementation of learning in schools, it was said that:

"In school implementation, when I teach in class usually the character values insert to the learning material to be taught, for example, the religious character, before starts the learning process we praying first and also students taught to carry out routine worship every day such as perform Dhuha Prayers in congregation and respect each other. The teacher also teaches the students honest character by advising them to be honest during exams or not to cheat. In terms of discipline, our students are taught to enter the classroom on time and orderly in participating in classroom learning, however there are still some students who are still late for class. The character of responsibility can be seen from the assignments that have been done. In its implementation, it appears that students have a sense of responsibility in doing the assignments. Meanwhile, the students taught the value of hard work by not to give up easily in solving problems or assignments given by the teacher. "(W/A/L/27/07/20/at: 11:30 WITA)". The interviews with teachers regarding the implementation process in learning at home can be seen in the following explanation.

"Regarding learning that is conducted at home at this time it is very different from learning at school because in its implementation there are still many obstacles faced such as lack of control from teachers and parents. The parents are busy in working, so they cannot monitor and control to their children in learning, many students are not online, adequate devices, the material is poorly understood and questions from students cannot be answered optimally in the learning process. Character values cannot be assessed because only a few characters can be assessed such as responsibility in doing assignments or not, discipline in the sense that students do assignments according to the time given by the teacher or not, and honest about the results of their own assignments or done by parents or answers from Internet. "(W/P/L/28/07/20/at: 10:15 WITA)".

In the implementation of character education, collaboration is needed with various parties, including schools, families and communities in order it can be implemented according to objectives. Therefore, the school needs to establish good communication with various parties as a means of sharing and evaluation to discuss the problems and obstacles that occur during the implementation process and to find the solutions to overcome the problems.

In addition to conducting interviews, researchers also made observations in junior high schools. The result of the observation can be seen in the following paragraph. 
"At 09:00 I saw the teacher inviting students to do learning activities outside the classroom in the learning process, I saw them memorizing verses which were a task given by the ustadzah (female teacher)". (O//27/07/20/at:10.30 WITA).

Based on the results of interviews, observation and documentation, it can be concluded that the implementation of character education at school and learning at home is very different because the implementation of character values in the learning process at school can be directly monitored by the teacher, while when studying at home the character values are not fully able to be monitored by the teacher, just the few values such as honesty, responsibility and discipline.

3) The Evaluation of the Implementation of Character Education for Junior High School Students in Sumbawa Regency

The results of the interview with Fakhruddin as the Principal of the School can be seen in the following paragraph.

"The evaluation that is conducted is usually once a week or once a month by the homeroom teacher so that the teacher can evaluate some problematic students in order the character values are taught to students that can make them into human beings who have character, so that the teacher must focus on these students. "(W/KP/L/27/07/20/at:10.30 WITA)".

Besides that, the teacher said that:

"In the process of evaluating, the teacher observes student habits, for example the teacher teaches religious values during prayer time, we give directions after prayer, observes from their health and interactions with friends and student behavior in the classroom so that the teacher can see the changes from students. "(W/A/L/27/07/20/at: 11:30 WITA)".

In addition to conducting interviews, researchers also made observations in junior high schools.

"At 08:40 the teacher conducts an evaluation such as evaluating their habits such as being honest in the case that the student does not cheat in exam and religious values such as prayer must be on time because that is the value of student discipline. When we apply it, we will easily direct the students to understand the learning. "(O/27/07/20/at: 11:30 WITA)".

Based on the results of interviews, observations and documentation conducted by researchers, it shows that the behavior of the students has been habituated according to the expected character values, for example from the results of interviews with the teacher that the character values of students have been seen to be implemented. This can be seen in the form of learning activities such as: being present on time, praying before and after learning, not cheating, prohibition of carrying communication tools during learning activities, tests and exams, keeping the classroom environment clean, carrying out picket assignments regularly. In the form of outside learning activities such as: praying Dzuhur in congregation on time and picking up the trash.

\section{B. Discussion}

The Plan of Character Education Planning for Junior High School Students in Sumbawa District

Based on the previous explanation that planning for character education for junior high school students by developing a syllabus and a plan for implementing learning by including character values to be developed.

Teacher guidelines in planning character education in schools are based on the appropriate character rules requested by the department, then schools combine it with the religious approach so that students can apply it in everyday life according to Islamic teachings. Teaching character values commonly used by private junior high school students in Sumbawa Besar district include honest character, discipline, responsibility, and hard work. With this planning, the implementation will be more focused in achieving it.

Based on the above discussion, it can be concluded that before implementing character education in junior high school students, it is necessary to plan through program making and teaching character values in learning activities. The planning learning activities are conducted through learning media such as syllabus and lesson plans by implementing the character values developed which are guided by the learning media that have been made.

1. The Implementation of Character Education for Junior High School Students in Sumbawa District.

Implementation is an activity to realize the plan into concrete actions to achieve goals effectively and efficiently in order to obtain satisfactory value and results. The implementation of character education is the core activity of character building in students. The implementation of character education has been conducted in teacher learning to insert character values in the material being taught such as religion, honesty, discipline, responsibility and hard work.

In its implementation in junior high school, teachers conducted learning activities by using several character values in students. However, based on the results of the documentation of character values that are often taught in the learning process, namely: religious, honest, disciplined, responsibility. and hard work.

Based on the description of character values that are often taught by teachers in learning, it can be concluded that junior high school students in Sumbawa district have integrated character values into learning activities. This can be seen from the results of observations, interviews, and documentation related to the teaching of character values by the teacher. The most common characters implemented in learning processes are religious, honesty, discipline, responsibility, and hard work.

2. The Evaluation of Character Education for Junior High School Students in Sumbawa District.

Evaluation of the implementation of character education is carried out to measure students who have or do not have one or more characters that determined by the school within a certain period of time. Therefore, the substance of the evaluation in the context of character education is an effort to compare the behavior of students at school with the character 
at home that is determined by the teacher and assisted by the parents of students. In this case the school provides an observation book to find out the progress of students in school and assesses the whole program to observe the success of the character education program in accordance with the school rules to be achieved. Therefore, there must be an evaluation system to assess the development of the character education program that is successfully implemented.

The evaluation process carried out by the school is that the teacher will visit the family of students who have problems. It is beneficial to assess students' characteristics and provide guidance to teach good character to them. Hence, the students will be able to improve themselves and learn to understand the correct character values towards the attitudes of others.

Based on the results of observations and interviews, student behavior has shown habituation in accordance with the expected character values, for example, from the results of interviews with the teacher, it was stated that the character values of the students had been seen. This is manifested in the form of learning activities such as: getting used to being present on time, praying before and after learning, not cheating, not bringing communication tools during learning activities, tests, and exams, maintaining the cleanliness of the classroom environment, carrying out cleaning shift regularly.

\section{The Supporting Factors of Character Education for} Junior High School Students

The successful implementation of character education for junior high school students cannot be separated from supporting factors such as: (a) government policies, (b) conducive environmental conditions, (c) school facilities and infrastructure that support the implementation of character education, (d) human resources (teachers), (e) conducive situation and support from all school members to facilitate the implementation of character education.

From the aforementioned statement, it can be concluded that the supports for the implementation of character education in junior high schools are the government policies that support character education, school environmental conditions, school facilities and infrastructure, good human resources and support from school members.

\section{The Obstacles in Implement the Character Education for Junior High School Students}

Based on the research results, there are several obstacles faced by the junior high school in Sumbawa district in implementing character education, including:

(a) Household environment. This is because most of the students' parents have divorced, which affects the psychology of students.

(b) The community environment, namely the condition of a residential area with a densely populated area is very different because of the form of association in attitudes, behavior and words from people around.

(c) School Origin. This is very influential because students who study at the same elementary school foundation already know the rules and regulations taught by the teachers (male/ustadz or female/ustadzah) at school so it is not difficult to teach them back and students who are in non-elementary schools from the same foundation as private junior high schools, the teachers have to work hard to teach the rules and behave properly according to the school rules.

(d) Bullying, for example at home and in the community, the students behave well, but when they starts go to school, they feel scared because they obtain bullied when in elementary school and eventually affected the students' mental state. So, the teacher must collect information from the students themselves and their parents.

Some of the obstacles for teachers in achieving character education are the influence of the household environment, the community environment, the origin of the school and bullying so that it makes teachers less optimal in monitoring student activities at home, so that the bad character that is obtained from the community environment to the school can affect the character of other students. In the environment where students live, students more interact with the community so that the character of the environment community is more dominant due to the divorce parents' problem.

From the discussion, it can be concluded that in the implementation of character education for junior high school students there are several obstacles, namely the influence of the household environment, community environment, school origin and bullies. However, even though there are several obstacles the school continues to try and work hard in teaching character values to students.

5. The Solutions in Solving Problems to Implement the Character Education for Junior High School Students.

Every process of implementing character education in learning activities always has obstacles. Here are the solutions to overcome these obstacles:

(a) The school reminds us if there are obstacles in the implementation of character education and work together to equalize the perceptions of school members so that the implementation of character education is as expected.

(b) Establishing communication with parents about the development of students so that the teachers can find out about the development of students' attitudes and behavior when they are at home.

(c) It takes support, attention, and supervision from parents in forming the character of students, because character education is not only the responsibility of the teacher, but responsibility of the parents also in order can be implemented in the environment where they live.

(d) Providing advice to students about the importance of character education and it needs patience and hard work from all school members in forming the diverse character of students. 
Although there are several obstacles, schools have tried to overcome these obstacles so that their application to students can be achieved. Hence, it can be concluded that junior high school in Sumbawa Besar Regency have implemented character education for students

\section{CONCLUSION}

Based on the results of research and discussion regarding the implementation of character education for junior high school students in Sumbawa district, the following conclusions can be drawn:

\section{The Plan of Character Education}

The character education planning has been arranged by the principal so that the teacher makes a syllabus and lesson plan so that it can teach character values in the learning process.

2. The Implementation of Character Education.

In implementing character education in learning activities, the teacher inserts some character values in the learning process. These character values include: religion, honesty, discipline, responsibility and hard work.

3. The Evaluation of the Implementation of Character Education.

Evaluation of the implementation of character education is conducted to measure whether already have or not had one or more characters that implemented by the school in a certain period of time. The evaluations process conducted by the school are the home/family visit for the students who have problems to evaluate the character of students and the teacher provides directions to parents of students to teach good character to students so they can change and learn to understand the correct character values for behaving towards others.
4. The Supporting Factors for the Implementation of Character Education.

The supporting factors for the implementation of character education are government policies related to character education, school environmental conditions, school facilities and infrastructure, adequate human resources and support from school members.

\section{ACKNOWLEDGMENT}

This research was supported by many parties, including: LPPM UNSA, Faculty of Teacher Training and Education, the junior high schools in Sumbawa district. In this case do not forget to deliver a deep gratitude for the support in the form of knowledge, experience and financial assistance, hopefully the parties involved will receive a reward from Allah SWT.

\section{REFERENCES}

[1] Samani. Muchlas, Pendidikan Karakter. 2012

[2] Doni Koesoema, Pendidikan Karakter; Strategi Mendidik Anak di Zaman Global. 2010.

[3] Nining Andriani, Analisis Aspek-aspek dalam Membentuk Karakter pada Pembelajaran IPS Ekonomi. 2018.

[4] Lickona T, Educating For Character. 1991.

[5] Akhmad Muhaimin, "No Title," Urgensi Pendidik. Karakter, vol. 27, 2011.

[6] Majid A, Pendidikan Karakter Perspektif Islam. 2011.

[7] Agus Wibowo, Pendidikan Karakter; Strategi Membangun Karakter Bangsa. 2012.

[8] Endang Widi Winarni, Teori dan Praktik Penelitian Kuantitatif, Kualitatif. 2018.

[9] Sugiyono, Educational Research Methods Qualitative and Quantitative Approaches $R$ \& $D$ (Metode Penelitian Pendidikan Pendekatan Kuantitatif Kualitatif Dan $R \&$ D). 2010.

[10]Mujahidin. Anwar, Metode Penelitian Kualitatif di Bidang Pendidikan. 2019. 